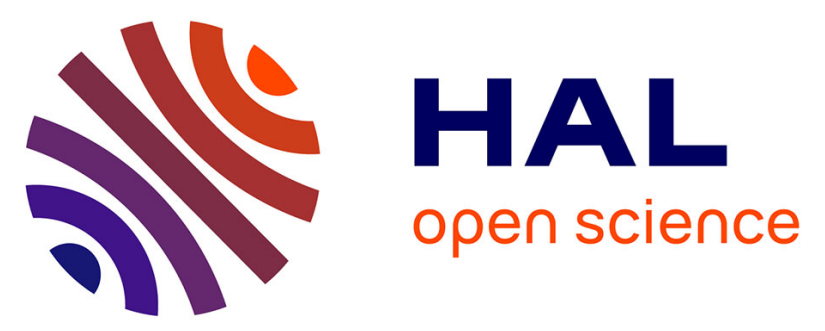

\title{
New Clues on the Origin of the "Inca Mirror" at the Museum National d'Histoire Naturelle in Paris
}

Thomas Calligaro, Pierre-Jacques Chiappero, François Gendron, Gérard Poupeau

\section{- To cite this version:}

Thomas Calligaro, Pierre-Jacques Chiappero, François Gendron, Gérard Poupeau. New Clues on the Origin of the "Inca Mirror" at the Museum National d'Histoire Naturelle in Paris. Latin American Antiquity, 2019, pp.1-7. 10.1017/laq.2019.3 . hal-02107042

\section{HAL Id: hal-02107042 https://hal.science/hal-02107042}

Submitted on 23 Apr 2019

HAL is a multi-disciplinary open access archive for the deposit and dissemination of scientific research documents, whether they are published or not. The documents may come from teaching and research institutions in France or abroad, or from public or private research centers.
L'archive ouverte pluridisciplinaire HAL, est destinée au dépôt et à la diffusion de documents scientifiques de niveau recherche, publiés ou non, émanant des établissements d'enseignement et de recherche français ou étrangers, des laboratoires publics ou privés. 


\title{
New Clues on the Origin of the "Inca Mirror" at the Museum National d'Histoire Naturelle in Paris
}

Thomas Calligaro, Pierre-Jacques Chiappero, François Gendron, and Gérard Poupeau†

\begin{abstract}
Since at least 1742, the mineralogical collection of the Muséum National d'Histoire Naturelle (MNHN) in Paris has hosted, under the reference number $22 . U$, a biconvex lens-shaped obsidian artifact, also described as a mirror, measuring $250 \mathrm{~mm}$ in diameter and finely polished on both faces. It has usually been ascribed to the shipment sent by Hernán Cortez in 1522 to the Emperor Charles V, which was captured by a French privateer. We investigated the object using modern techniques. The elemental composition of the obsidian determined by the particle induced X-ray emission (PIXE) method showed that the raw material originates from the Mullumica deposit (Ecuador). Documentary investigations revealed that the lens (renumbered No. 176.101) was sent in 1737 from Quito, Ecuador (at that time part of the viceroyalty of Peru), to France by members of the Godin-La Condamine geodesic expedition (1735-1743). The mirror is thus among the rare Ecuadorian archeological or colonial artifacts to have reached the Old World during the eighteenth century.
\end{abstract}

Keywords: Ecuador, Louis Godin, mirror, Mullumica, Muséum National d'Histoire Naturelle, de La Condamine, obsidian, PIXE

La colección de mineralogía del Museum National d'Histoire Naturelle (MNHN) de París conserva desde 1742 una lente de obsidiana $\left(n .{ }^{\circ} 22 . U ; \emptyset: 250 \mathrm{~mm}\right)$ finamente pulida en ambos lados. Tradicionalmente fue atribuida a los objetos enviados en 1522 al emperador Carlos V por Hernán Cortés y capturados por un corsario francés. A partir del re-estudio del material de archivo se consideró la necesidad de realizar un análisis de la obsidiana con técnicas modernas. La composición elemental de la obsidiana, determinada por espectrometría de rayos $X$ inducida por partículas (PIXE), permitió establecer que proviene del yacimiento de Mullumica (Ecuador). Asimismo, los documentos revelan el envío de este espejo en 1737 desde Quito (en ese momento Ecuador era parte del Virreinato del Perú) a Francia por los miembros de la expedición geodésica Godin - La Condamine (1735-1743). En consecuencia, dicha lente (renumerada 176.101) constituye uno de los raros objetos arqueológicoso coloniales ecuatorianos que han alcanzado el "Viejo Mundo" durante el siglo dieciocho.

Palabras Clave: Ecuador, Louis Godin, espejo, Mullumica, Muséum National d'Histoire Naturelle, de La Condamine, obsidiana, PIXE

\section{Description of the "Inca Mirror"}

$\mathrm{T}$ The artifact, which is part of the mineralogical-geological collection of the Muséum National d'Histoire Naturelle (MNHN) in Paris, is a polished lens of obsidian, measuring $250 \mathrm{~mm}$ in diameter and $20 \mathrm{~mm}$ in maximum thickness, mounted in a black-painted bronze circular frame on an oak pedestal (Figure 1). An old handwritten note under the base reads "Mirror of the Incas, Gallinace stone, Plinian Obsidian stone" [translation

Thomas Calligaro - Centre de Recherche et de Restauration des Musées de France, 14 quai François Mitterrand, 75001, Paris, France; PSL, Chimie Paris Tech-CNRS, Institut de Recherche Chimie Paris, UMR 8247

Pierre-Jacques Chiappero — Sorbonne Université, Muséum National d'Histoire Naturelle, Origines et Évolution, 61 rue Buffon, 75005, Paris, France

François Gendron — Sorbonne Université, Muséum National d'Histoire Naturelle, Homme et Environnement, UMR 7194, 1 rue René Panhard, 75013, Paris, France (francois.gendron@mnhn.fr, corresponding author)

Gérard Poupeau — Centre de Recherche en Physique Appliquée à l'Archéologie, UMR 5060, Université Bordeaux, 33607, Pessac, France

$\uparrow$ This author died before publication of the article.

Latin American Antiquity, pp. 1-7

Copyright (C) 2019 by the Society for American Archaeology doi:10.1017/laq.2019.3 


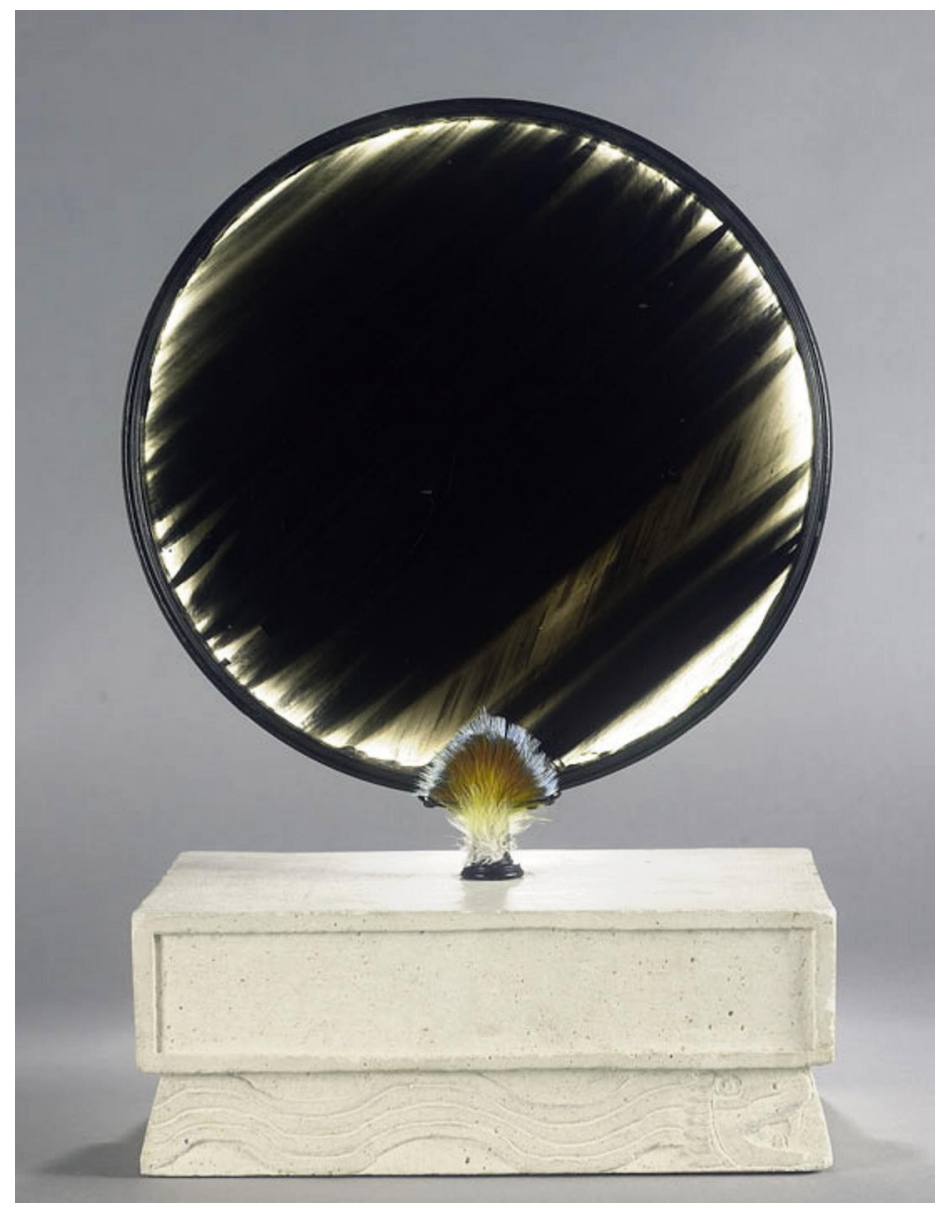

Figure 1. Obsidian "Inca mirror" No. 176.101 of the Muséum National d'Histoire Naturelle (Ø: $250 \mathrm{~mm}$ x $20 \mathrm{~mm}$ thickness). The plaster base and the feather decoration were added and made in a Mesoamerican style to conform to the supposed Mexican origin of the mirror. (Photograph by D. Vigears/C2RMF.)

by authors], with the number 22.U on the back of the label (Schubnel et al. 2001:31). Henri-Jean Schubnel, curator of the MNHN mineralogical collection, could not link this number to any reference in the museum catalogs and hence assigned to it the new reference 176.101.

\section{Historical Analysis}

In 1987, Mireille Simoni-Abbat suggested that the lens was part of the treasures sent by Hernán Cortés to Emperor Charles V, which was captured by the French privateer Jean Florin (Simoni-Abbat 1987:53; see also Supplemental Text 1). She also noted, however, that Dezallier d'Argenville reported the presence in "the gallery of the Natural History ... located in the Jardin [Royal] des Plantes Médicinales [currently the Jardin des Plantes], of a large biconvex plate of black and wavy crystal, found in the tombs of the Incas in Peru" (1742:199). ${ }^{1}$ All translations of primary sources are by the authors. The latter historical description, which is in good agreement with the appearance of the lens, rules out a Mexican origin.

It is known that Cortés used to take note of all objects he was shipping to the emperor, to his father, or to other influential Spaniards to prevent him against possible accusations of embezzlement. The lists of his treasures shipped to Spain do not mention an obsidian lens or a similar artifact (Martínez 1990:232-249). To determine 
how and when the object reached the Jardin Royal des Plantes médicinales (JRPM) therefore required a reappraisal of the historical records.

\section{On the Inca Trail}

Our bibliographic investigations of old descriptions of the MNHN and the JRPM collections found several mentions of this type of object. This section includes the most relevant and oldest ones.

In 1803, according to the Count de Caylus, who was himself citing Antonio de Ulloa, Louis de Launay reported that "the former inhabitants of Peru ... employed this stone to make mirrors" and that "we found in the tombs of the ancient Peruvians, two sorts of mirrors, some of Inca stone, a kind of pyrite, and others of gallinace stone: the Peruvians worked them on both sides into the shape of a lens, and polished both surfaces so that they reflect objects" (1803:363-364).

In 1802, Nicolas Jolyclerc gave an accurate description of obsidian mirrors:

One, which is called ... in Peru stone of gallinace or Inca mirror, is a black glass.... The inhabitants of Peru used it as a glass to make their mirrors.... One of these mirrors is displayed in the galleries of the National Museum of Paris. It is nine inches in diameter and ten lines thick; it is convex on both sides, but with a somewhat rough and uneven surface $^{2}(1802: 343)$.

In 1768, Valmont de Bomare devoted a paragraph to the stone of gallinace: it is a "kind of blackish glass, very hard and heavy, that the Peruvians use to make their mirrors," and "a very beautiful example may be seen in the King's Cabinet of Natural History; it was found in a remote tomb in the Pichencha [sic: Pichincha] mountains near Quito. It is nine inches in diameter and one face is more polished than the other" (1768:590).

Count de Caylus's dissertation on obsidian written in 1764 gave the key to the origin of mirror No. 176.101:

According to Mr. Godin, in a letter written to Mr. the Count de Maurepas ... The Stone of gallinace is a sort of very beautiful black crystal; its color evokes the name gallinace after a bird common in America.... The
Indians also call this stone money of the dead, guanucuna culqui, because it was their custom to bury pieces with their dead and shaped pieces are indeed found in their tombs... two such worked fragments are conserved in the Cabinet d'Histoire naturelle du Jardin du Roy. The larger, as Mr. Godin stated, is one of the most beautiful that we have seen from the country; it was found in a remote tomb in the mountains, near Quito; it is nine inches in diameter, and ten and half lines thick, convex on both sides but with unequal curvature, and one of its faces is more polished than the other; it would appear that the ancient Indians used it as a mirror [1764:485].

\section{The Godin-La Condamine Expedition to South America (1735-1743)}

Two major French scientific expeditions were mounted in 1735 and 1736 - the first to South America and the second to Lapland-to measure the angle of arc at the meridian in order to test Newton's theory that the terrestrial globe is flattened at the poles. Two Spanish naval officers-Antonio de Ulloa (1716-1795) and Don Jorge Juan y Santacilia (1703-1773) were seconded by King Philippe V of Spain (1683-1746) to the South American expedition led by Louis Godin (1704-1760).

At the end of the eight-year mission in 1743, de Ulloa published a travel journal. ${ }^{3}$ His report on the opening of the "Guasques" (burial mounds) is illustrated by drawings, notably Plate XVI, which represents the ruins of prehispanic buildings and the discovered artifacts (de Ulloa 1752). Along with pieces of ceramic artifacts and jewelry there are three wavy lenses pierced with a hole near the edge (Figure 2), although it is not clear that such obsidian mirrors are genuine artifacts from the prehispanic Andean cultures; these objects could be colonial and been fraudulently presented to the expedition team as archaeological relics.

\section{The Gallinace Stone}

The term "stone of Gallinace" employed by de Ulloa to describe the obsidian refers to the color of feathers from the black vulture 


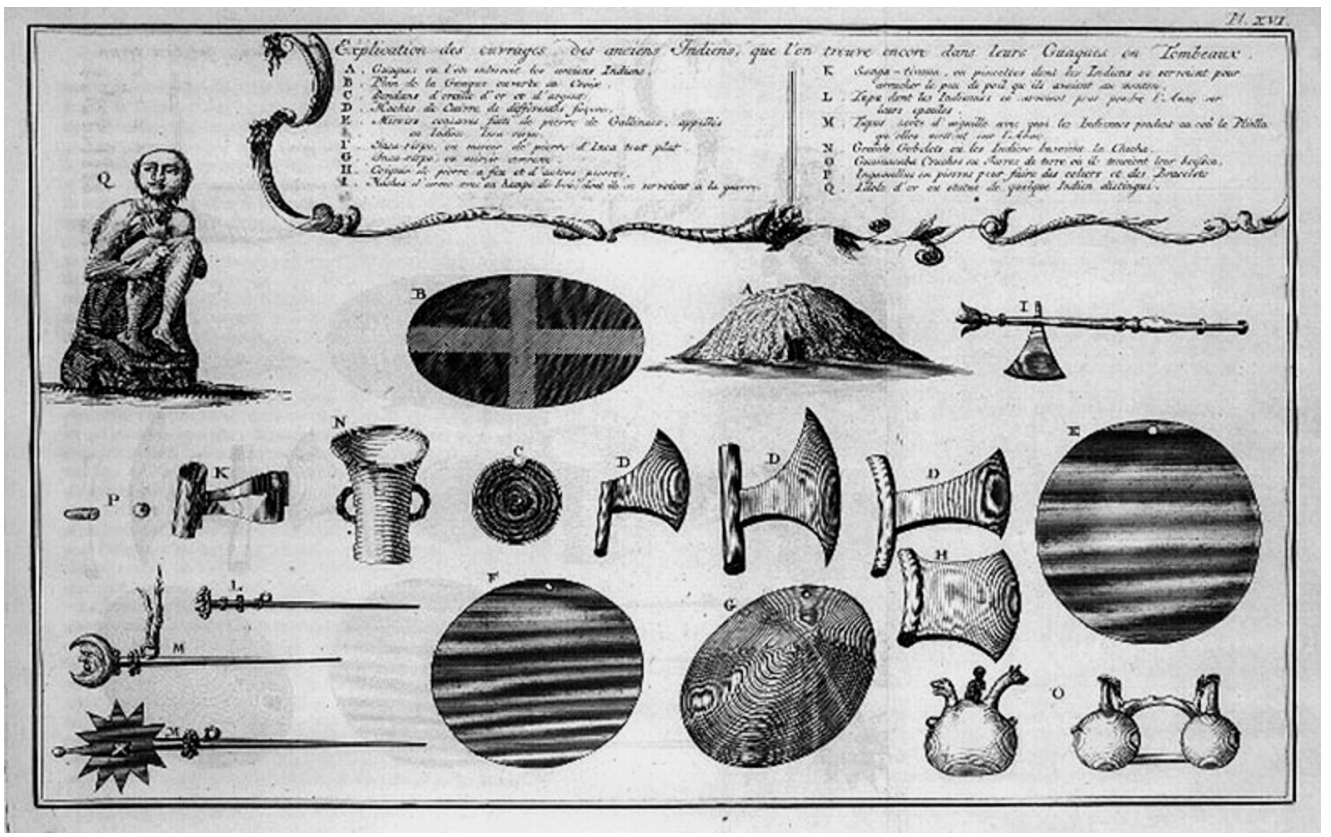

Figure 2. Plate XVI from Journal de Voyage of Antonio de Ulloa (1752) depicting three obsidian mirrors: E, F, and G.

Table 1. Composition of Obsidian from the "Inca Mirror" No. 176.101 Compared to that of the Mullumica and Callejones Sources in Ecuador.

\begin{tabular}{lrrrrrrrrrrrr}
\hline Obsidian Sources & $\mathrm{Na}_{2} \mathrm{O}$ & $\mathrm{Al}_{2} \mathrm{O}_{3}$ & \multicolumn{1}{c}{$\mathrm{SiO}_{2}$} & $\mathrm{~K}_{2} \mathrm{O}$ & $\mathrm{CaO}$ & $\mathrm{TiO}_{2}$ & $\mathrm{MnO}$ & $\mathrm{Fe}_{2} \mathrm{O}_{3}$ & $\mathrm{Zn}$ & $\mathrm{Rb}$ & $\mathrm{Sr}$ & $\mathrm{Zr}$ \\
\hline $176.101 \# 1$ & 3.22 & 12.91 & 77.43 & 4.33 & 0.79 & 0.13 & 0.05 & 0.79 & 35 & 171 & 161 & 103 \\
$176.101 \# 2$ & 3.24 & 12.94 & 77.39 & 4.35 & 0.80 & 0.13 & 0.05 & 0.76 & 35 & 178 & 155 & 96 \\
$176.101 \# 3$ & 3.26 & 12.99 & 77.16 & 4.31 & 0.87 & 0.13 & 0.06 & 0.85 & 36 & 176 & 162 & 119 \\
$176.101 \# 4$ & 3.25 & 12.94 & 77.31 & 4.34 & 0.81 & 0.12 & 0.05 & 0.79 & 37 & 185 & 167 & 92 \\
$176.101 \# 5$ & 3.27 & 13.01 & 77.21 & 4.33 & 0.83 & 0.12 & 0.05 & 0.79 & 35 & 175 & 172 & 94 \\
$176.101 \# 6$ & 3.25 & 12.89 & 77.37 & 4.35 & 0.81 & 0.12 & 0.06 & 0.76 & 38 & 177 & 147 & 82 \\
$176.101 \# 7$ & 3.30 & 12.99 & 77.31 & 4.31 & 0.82 & 0.13 & 0.05 & 0.76 & 34 & 172 & 149 & 112 \\
$176.101 \# 8$ & 3.29 & 12.83 & 77.46 & 4.35 & 0.79 & 0.12 & 0.05 & 0.73 & 35 & 168 & 148 & 84 \\
$176.101 \# 9$ & 3.28 & 12.93 & 77.29 & 4.33 & 0.81 & 0.12 & 0.05 & 0.81 & 34 & 173 & 160 & 91 \\
$176.101 \# 10$ & 3.27 & 12.95 & 77.31 & 4.34 & 0.83 & 0.12 & 0.05 & 0.77 & 39 & 180 & 163 & 99 \\
$176.101 \# 11$ & 3.33 & 12.88 & 77.36 & 4.32 & 0.82 & 0.12 & 0.05 & 0.75 & 36 & 174 & 152 & 101 \\
Mean value & 3.27 & 12.93 & 77.33 & 4.33 & 0.81 & 0.12 & 0.05 & 0.78 & 36 & 175 & 158 & 98 \\
Std. dev, & 0.03 & 0.05 & 0.09 & 0.02 & 0.02 & 0.00 & 0.00 & 0.03 & 2 & 5 & 8 & 11 \\
Mullumica & 4.10 & 13.49 & 76.36 & 3.80 & 0.84 & 0.17 & 0.04 & 0.86 & 34 & 145 & 173 & 114 \\
Std. dev. & 0.31 & 0.53 & 1.05 & 0.27 & 0.14 & 0.03 & 0.01 & 0.16 & 4 & 6 & 43 & 33 \\
Callejones & 4.43 & 14.04 & 75.41 & 3.49 & 1.01 & 0.19 & 0.05 & 1.03 & 37 & 136 & 233 & 136 \\
Std. dev. & 0.33 & 0.74 & 1.54 & 0.13 & 0.21 & 0.05 & 0.01 & 0.28 & 8 & 10 & 73 & 5 \\
\hline
\end{tabular}

Note: Oxide concentrations are given in weight percentage, whereas elemental trace elements are given in $\mathrm{kg} / \mathrm{g}(\mathrm{ppm})$.

(Coragyps atratus), similar to that of the dark bands found in the Gallinace stone, as seen in the obsidian lens No. 176.101. De Ulloa specifies: "Two kinds of stone mirrors are found in the Guasques, some made of Inca stone, and others of Gallinace stone.... The name comes from its color, like that of the Gallinazo.... Among the mirrors of the latter type, some are flat, others are concave and yet others are convex" (1752:L.VI, chap. XI, 383-385, 392). 


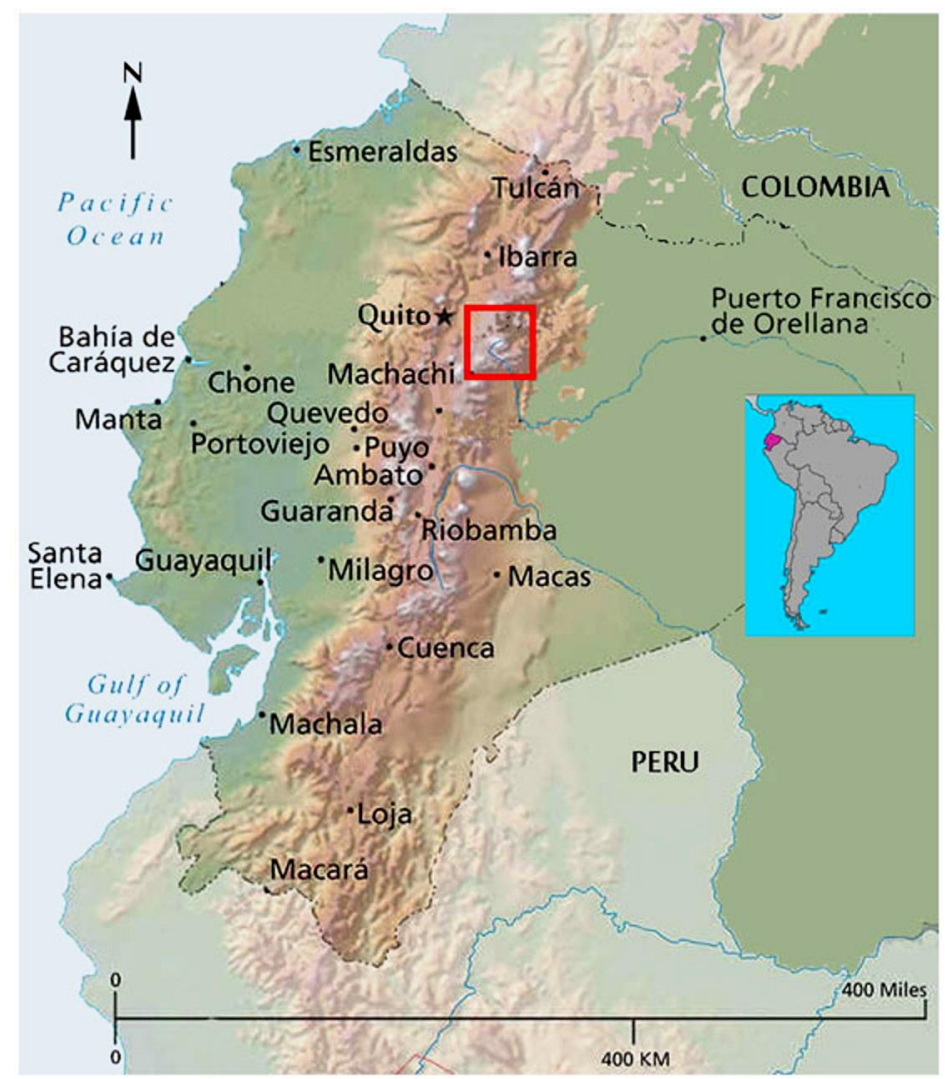

Figure 3. The box indicates the Sierra de Guamaní, the site of the Mullumica obsidian source.

Shipments from the Godin-La Condamine Expedition to the Jardin du Roy

The archaeological artifacts collected by the astronomers in Ecuador were sent to various destinations. La Condamine reports that the shipments of June 1737 and October 1740 were lost, but that two others reached their French recipients: Charles Cisternay du Fay (1698-1739), intendant of the Jardin du Roy, and Jean Frédéric Phélypeaux, Count de Maurepas (1701-1781), navy minister under Louis XV: "The cabinet of the Jardin du Roy houses our first shipments, sent together from our islands and from Portobelo [sic: Portobello, Panama] in 1735, and another shipment made from Quito in 1737, by Mr. Godin, in which I was much involved" (de La Condamine 1751:104, footnote).

Excerpts from a letter by Godin confirm this shipment: "I sent to my lord the Count de Maurepas, in the month of May 1737 from Quito... a crate containing various curiosities to the address of my lord the Count de Maurepas: it was received by $M$. du Fay, and apparently distributed in the cabinet of the King" (Godin 1802 [1752]:214, 217). The lens arrived in Paris in 1737 and was later mounted in its bronze frame.

\section{Analytical Techniques}

All obsidian slabs and mirrors conserved at the MNHN (Musée de l'Homme) and at the Musée $\mathrm{du}$ Louvre were nondestructively analyzed by the particle induced X-ray emission (PIXE) method using the AGLAE accelerator of the Centre de Recherche et de Restauration des Musées de France (C2RMF), which had been placed in the Musée du Louvre for a previous study (Calligaro et al. 2005; Supplemental Figure 1). 
PIXE Analysis of Obsidian Lens No. 176.101

The obsidian of mirror No. 176.101 is translucent; it exhibits parallel dark and light bands alternating across much of the disc. This banding of microscopic inclusions probably reflects the direction of the flow during its formation. The chemical composition of the material measured on 11 spots located every $2 \mathrm{~mm}$ across a band on the more polished face varies little (Table 1), reflecting the homogeneity of the glass matrix. Comparison of the recorded compositions with those of obsidian from Mexican sources reported in Calligaro and colleagues (2005) and elsewhere (Cobean 2002) disproves a Mexican origin, particularly considering the presence of three trace elements: manganese $(\mathrm{Mn})$, rubidium $(\mathrm{Rb})$, and zirconium (Zr). The museum lens contains 360 $\pm 32 \mu \mathrm{g} / \mathrm{g} \mathrm{Mn}$. Only two Mexican sources have Mn concentrations in this range: Paredón (Puebla State; $358 \pm 18 \mu \mathrm{g} / \mathrm{g}$ ) and Otumba (Mexico State; $380 \pm 26 \mu \mathrm{g} / \mathrm{g}$ ). All other Mexican sources have either markedly higher or lower concentrations. The low $\mathrm{Zr}$ concentration in the lens $(97 \pm$ $22 \mu \mathrm{g} / \mathrm{g}$ ) excludes the Paredón deposit (193 \pm $14 \mu \mathrm{g} / \mathrm{g}$ ), whereas the high $\mathrm{Rb}$ concentration in the lens $(175 \pm 9 \mu \mathrm{g} / \mathrm{g})$ excludes the Otumba deposit $(118 \pm 5 \mu \mathrm{g} / \mathrm{g})$. Thus the chemical composition of the obsidian of the lens does not correlate with any analyzed obsidian source from Mexico. The uncertainties given for our measurements correspond to two standard deviations (95\% confidence level).

In contrast, the composition matches that of other American sources. It corresponds within two standard deviations to the reported values of the Ecuadorian obsidian deposits, in particular that of Mullumica, Sierra de Guamaní (Table 1); it is a little similar to those from Callejones, Pichincha province (Figure 3; Bellot-Gurlet et al. 1999, 2008). The relatively large range for the Mullumica and Callejones compositions is due to the well-known natural heterogeneity of these obsidian flows.

\section{Conclusion}

PIXE analyses indicate that the obsidian of the lens No. 176.101 from the MNHN mineralogy collections in Paris originate from the Mullumica deposit located in the Sierra of Guamaní,
Ecuador. This provenance is consistent with the writings by Valmont de Bomare in 1768. This finding, combined with bibliographical research, allowed us to identify the lens as the only known artifact that can be assigned to the Godin-La Condamine geodesic expedition to Ecuador (1735-1743). This mirror was reputed in Quito for its fascinating appearance when it was offered to the expedition and delivered to the JRPM in France in 1737. Accordingly, it is among the rare artifacts from Ecuador to have reached Europe during the eighteenth century. Doubt remains as to the prehispanic origin of this obsidian mirror because few similar artifacts were found in archeological contexts on Ecuadorian sites (La Tolita) and those that were found exhibit very different shapes (Uhle 1927:figure 21; Valdez 1987:72).

Acknowledgments. The research project on the obsidian mirrors of the MNHN benefited from the financial help of the French Ministry of Research contract ACI (2005-2008), "Du Chopper au brillant." The authors thank Timothy Greenland for his help in English translation. This article is dedicated to the memory of Gérard Poupeau.

\section{Notes}

1. All translations of primary sources are by the authors.

2. Using the units of length employed in France before the introduction of the metric system $(1$ inch $=27.07 \mathrm{~mm}$; 1 line $=2.256 \mathrm{~mm}$ ), this corresponds to $\varnothing: 243.63 \mathrm{~mm}$ and a thickness of $23.68 \mathrm{~mm}$. The dimensions of the lens No. 176.101 are $\varnothing: 252 \mathrm{~mm}$ and its thickness in the center is $20 \mathrm{~mm}$.

3. As did other members of this historical expedition, Pierre Bouguer (1744 [1698-1758]) and Charles-Marie de La Condamine $(1745,1751)$.

Data Availability Statement. The obsidian mirror No. 176.101 is exhibited at the Mineralogical Gallery of the Museum national d'Histoire Naturelle, 36 rue Geoffroy St-Hilaire 75005, Paris, France.

Supplemental Materials. For supplementary material accompanying this report, visit https://doi.org/10.1017/laq.2019.3

Supplemental Text 1. More details regarding the "Inca Mirror" of the MNHN.

Supplemental Figure 1. Obsidian "Inca Mirror" No. 176.101 during its analysis by the AGLAé probe in 2006. (Photograph courtesy of D. Vigears/C2RMF.)

\section{References Cited}

Bellot-Gurlet, Ludovic, Gérard Poupeau, Olivier Dorighel, Thomas Calligaro, Jean-Claude Dran, and Joseph Salomon 
1999 A PIXE/Fission-Track Dating Approach to Sourcing Studies of Obsidian Artefacts in Colombia and Ecuador. Journal of Archaeological Science 26: $855-860$.

Bellot-Gurlet, Ludovic, Olivier Dorighel, and Gérard Poupeau

2008 Obsidian Provenance Studies in Colombia and Ecuador: Obsidian Sources Revisited. Journal of Archaeological Science 35:272-289.

Bouguer, Pierre

1744 Relation abrégée du voyage fait au Pérou par MM. De l'Académie royale des Sciences, pour mesurer les degrés du méridien aux environs de l'équateur, \& en conclure la figure de la terre. In Histoire et Mémoires de l'Académie royale des Sciences de Paris, edited by Académie des sciences (France), pp. 249-298. Imprimerie Royale, Paris

Calligaro, Thomas, Jean-Claude Dran, Stéphane Dubernet, Gérard Poupeau, François Gendron, Eric Gonthier, Olivier Meslay, and Denise Tenorio

2005 PIXE Reveals that Two Murillo's Masterpieces Were Painted on Mexican Obsidian Slabs. Nuclear Instruments and Methods in Physics Research Section B: Beam Interactions with Materials and Atoms 240 (1-2):576-582.

Cobean, Robert H.

2002 Un mundo de obsidiana. Minería y comercio de un vidrio volcánico en el México antiguo. Instituto Nacional de Antropología e Historia, University of Pittsburgh, Serie Arqueología de México, México.

de Caylus, Le Comte, Anne Claude Philippe

1764 Examen d'un passage de Pline dans lequel il est question de la pierre obsidienne. In Mémoires de littératures, tirés des registres de l'Académie des Inscriptions et Belles-Lettres, Vol. 30, edited by Académie des inscriptions et belles-lettres (France), pp. 457-502. Imprimerie Royale, Paris

de La Condamine, Charles-Marie

1745 Relation abrégée d'un voyage fait dans l'intérieur de l'Amérique méridionale. Veuve Pissot, Paris.

1751 Journal du voyage fait par ordre du roi, à l'Équateur, servant d'introduction historique à la mesure des trois premiers degrés du méridien. Imprimerie Royale, Paris.

de Launay, Louis

1803 Minéralogie des Anciens, Tome I. Chez Weissenbruch, Chez Garney, Bruxelles de Ulloa, Antonio

1752 Voyage historique de l'Amérique méridionale fait par ordre du roi d'Espagne par don George Juan et par don Antonio de Ulloa. 2 vols. Arkstee and Merkus, Amsterdam.

Dezallier d'Argenville, Antoine, Joseph

1742 L'Histoire naturelle éclaircie dans deux de ses parties principales, la lithologie et la conchyologie dont l'une traite des pierres et l'autre des coquillages. De Bure l'Aîné, Paris.

Godin, Louis

1802[1752] Lettre IX de M. Godin. In Lettre inédites d'Henri IV et de plusieurs personnages célèbres, edited by Antoine Sérieys, pp. 214-217. Henri Tardieu, Paris.

Jolyclerc, Nicolas

1802 Cours de minéralogie, rapporté au tableau méthodique des minéraux. Veuve Panckoucke, Paris.

Martínez, José Luis (editor)

1990 [sixteenth century] Documentos cortesianos 15181528: secciones I a III, Vol. I. Universidad Nacional Autónoma de México-Fondo de Cultura Económica, México, DF.

Schubnel Henri-Jean, Pierre-Jacques Chiappero, and Éric Gonthier.

2001 Mineral Treasure of the French Natural History Museum, Precious Crystals, Gemstones and Objets d'Art. 3rd. ed. Muséum National d'Histoire Naturelle/ TotalFinaElf/Association Française de Gemmologie, Paris.

Simoni-Abbat, Mireille

1987 Le miroir de l'Inca. In La Pierre et l'Homme, edited by Teresa Battesti, and Heri-Jean Schubnel, p. 53. Muséum National d'Histoire Naturelle, Paris.

Uhle, Maximilian

1927 Estudios Esmeraldeños. Anales de la Universidad Central 39(262):219-311.

Valdez, Francisco

1987 Proyecto arqueológico "La Tolita" (1983-1986). Museo del Banco Central del Ecuador, Quito.

Valmont de Bomare, Jacques-Christophe

1768 Dictionnaire Raisonné, Universel d'Histoire Naturelle ; contenant l'Histoire des Animaux, des Végétaux et des Minéraux, Tome IV. Lacombe, Paris.

Submitted February 9, 2018; Revised July 23, 2018;

Accepted January 14, 2019 